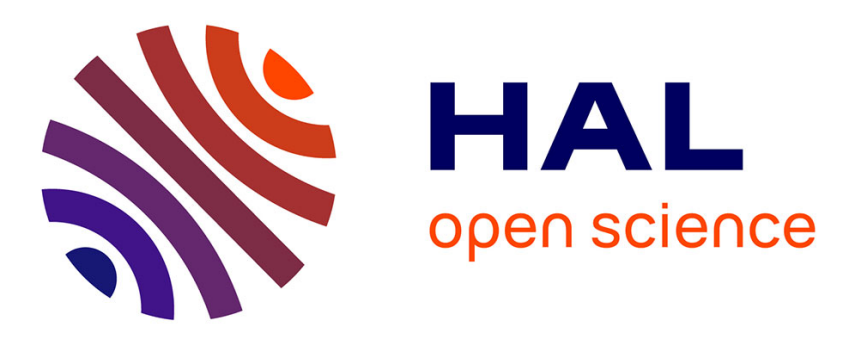

\title{
A multi-model approach to contact-induced language change
}

Claudine Chamoreau, Isabelle Léglise

\section{To cite this version:}

Claudine Chamoreau, Isabelle Léglise. A multi-model approach to contact-induced language change. Dynamics of Contact-induced language change, Mouton de Gruyter, pp.1-15, 2012. halshs-00672263

\section{HAL Id: halshs-00672263 \\ https://shs.hal.science/halshs-00672263}

Submitted on 27 Feb 2012

HAL is a multi-disciplinary open access archive for the deposit and dissemination of scientific research documents, whether they are published or not. The documents may come from teaching and research institutions in France or abroad, or from public or private research centers.
L'archive ouverte pluridisciplinaire HAL, est destinée au dépôt et à la diffusion de documents scientifiques de niveau recherche, publiés ou non, émanant des établissements d'enseignement et de recherche français ou étrangers, des laboratoires publics ou privés. 


\title{
A multi-model approach to contact-induced language change
}

\author{
Claudine Chamoreau and Isabelle Léglise
}

This volume deals with some never before described morphosyntactic variations and changes appearing in settings involving language contact. The primary purpose of the articles it presents is to identify different factors in language change. These changes are not treated as phenomena amenable to explanation from a single source: they constitute a dynamic domain of complex, complementary, and correlated processes that have to be treated with a finegrained approach.

The development of morphosyntactic structures in a situation of language contact should not be analyzed through a single lens. Contact-induced changes are generally defined as dynamic and multiple, involving internal change as well as historical and sociolinguistic factors. The identification and consideration of a variety of explanations constitutes a first step; analyzing their relationships forms a second. Only a multifaceted methodology enables this fine-grained approach to contact-induced change. A range of methodologies are proposed in the following chapters, but they generally have their roots in a typological perspective. The contributors recognize the precautionary principle: for example, they emphasize the difficulty of studying languages that have not been described adequately and for which diachronic data are not extensive or reliable, and they warn of the dangers of hypothesizing beyond the evidence and identifying possible tendencies that can never be confirmed definitively.

Three main perspectives on contact-induced language change are presented here, corresponding to three possible approaches to discussing the subject as part of a complex whole. The first explores the role of multilingual speakers in contact-induced language change, especially their spontaneous innovations in discourse. The second explores the differences between ordinary contact-induced change and change in endangered languages. The third discusses various aspects of the relationship between contact-induced change and internal change.

\section{The role of speakers and settings}

Historical linguists claim that change is unpredictable; even the most common or frequent change does not inevitably occur in a particular language or in a particular situation (Faarlund 1990; Lass 1980). This is also true for contact-induced changes: "any search for deterministic predictions of language change is bound to fail, whether the focus is on internally-motivated change or on contact-induced change" (Thomason 2000: 173). Language changes are thus unpredictable partly because speakers' attitudes are unpredictable, but above all because "there are no linguistic constraints on interference" (Thomason 2001: 85).

\section{Contact-induced change and communicative goals}

Social factors are fundamental to the definition of contact phenomena. Thomason (2001; see also Thomason and Kaufman 1998) has proposed a typology of interference mechanisms, 
establishing distinctions between language shift and language maintenance, language learning and language creation. It is crucial to take these factors into account, but the correlation between a specific type of social setting and a structural modification due to language contact is not always clear. The same effect may be observed with respect to language shift and language maintenance (see for example the rise of definite and indefinite articles in various languages, as discussed by Matras, Stolz, and Manterola, this volume).

Yaron Matras discusses the role of the social prestige of a language, often defined in terms of political, economic, or public dominance. He gives evidence to show that asymmetry in the social roles of the languages may determine the direction of change, but does not necessarily explain the motivation for structural change. The relationship between social settings and structural factors in contact-induced change is a crucial question, which Matras tackles through an integrated approach that links social context, conversational pressure and communicative intent, and the specific functional role of the structure or category in question. He examines the linguistic attitudes of multilingual speakers who make use of a complex repertoire in order to attain their communicative goals.

One of Matras' objectives is to identify the relationship between spontaneous innovations in discourse and the processes of language change through the propagation and stabilization of these innovations in communication. His hypothesis is that innovations are not arbitrary but driven by a communicative purpose, and that contact-induced change is the product of the creativity of speakers who seek new ways to achieve goal-oriented tasks in communicative interaction. He claims that contact-induced language change is the result of speakers' creativity in exploiting the full range of options available in their complex linguistic repertoire, and explores the ways in which lexical insertions may become lexical borrowings when they become a regular feature of the language in which they are inserted or when they are used in monolingual contexts. The innovator's social potential to influence others is another factor in play here. Matras thus shows that social and structural factors are involved in facilitating or constraining the successful propagation of innovations throughout a speech community.

\section{Contact-induced change as an innovation}

Heine (2006) argues that "speakers recruit material available in $\mathrm{R}$ (the replica language) to create new structures on the model of $\mathrm{M}$ (the model language) and ... rather than being entirely new, the structures created in $\mathrm{R}$ are built on existing use patterns and constructions that are already available in R." This creation is understood as a process by which the speakers of the receiving language look for methods of establishing equivalence relations between their language and the source language, generally appropriating a feature or structure of a source language and adapting it in their own language. Creative activity is an important part of contact-induced change, as is well-known and described in many studies in which informants are portrayed as "unpredictable speakers" (Thomason 2001) or "language builders" (Hagège 1993).

However, some studies make a distinction between the creation and the simple addition of a new structure. The former is a well-known activity, which adopts the model of the source language and may modify it to adapt its structure to the receiving language. The latter, less attested, is characterized by the emergence of a structure that is clearly a consequence of contact, but is not produced on the model of the receiving language nor on that of the source language. 
Claudine Chamoreau describes the structural and typological consequences of the contact between Purepecha (isolate, Mexico) and Spanish in the domain of comparative constructions. It is clear that Purepecha has been modified in this domain under the influence of Spanish in three different ways. Firstly, the Spanish particle type más...que has been borrowed and replicated. Another particle type may be associated with an original construction attested in Lengua de Michoacan (a pre-contact replica language), the coordinated type with negation (Lit. 'It is warmer inside the house and not outside.'). This type is a creation resulting from contact-induced and internal changes. A third particle type is also accompanied by a locative phrase, as in Spanish más...de...que. However, another specific construction was created on the model neither of the receiving language nor of Spanish, the contact language: a construction in which the Spanish preposition entre is used in order to form a comparison. This construction is clearly influenced by Spanish, but it displays a use in Purepecha that deviates from the patterns of comparative construction in Lengua de Michoacan and in Spanish, and from the use of the morpheme entre in Spanish. The transfer of Spanish entre allows Purepecha to innovate in the expression of the comparison of superiority and in the context of use of this Spanish preposition.

In the contact linguistics literature, it is rare to find a feature described as a new structure that diverges from both the languages in contact. In Purepecha, Chamoreau links this innovation with two factors: an identity issue, that is, the desire of the speakers of the villages in which this construction is found to distinguish themselves from others on linguistic and cultural levels, and also a cross-linguistic tendency to connect comparison with location and to express comparison through a locative type. Chamoreau claims that innovative activity as a choice seems to be caused both by sociolinguistic factors and cross-linguistic tendencies.

\section{Contact-induced change and endangered languages}

Another topic explored is the difference between ordinary contact-induced change and that occurring in endangered languages. Many specific linguistic changes have been cited as markers of obsolescence, in particular reduction of paradigms, reduction in the use of grammatical categories, and loss of grammatical categories or of optional mechanisms in morphology or syntax (for example Dorian 1981; Sasse 1990). However, these same processes are also attested as contact-induced changes (Thomason 2001). Both language contact and language obsolescence may promote structural changes, but specific criteria have not yet been established to distinguish between changes that can be seen as signs of obsolescence in process and changes that might occur under language contact or multilingual settings. The view that contact-induced changes and the consequences of language decay have to be distinguished is relatively unusual among specialists in the field; it has often been said that the types of change observable in an obsolescent language do not differ from those occurring in other kinds of contact settings (Dorian 1981: 151; Romaine 1989: 71).

Campbell and Muntzel (1989: 195) try to draw a distinction between obsolescent processes and changes that can be attributed to language contact, while acknowledging that it is not always an easy distinction to make. They use examples from Pipil, but note that "one might suspect that these Spanish-influenced structural mutations away from relational nouns reflect the kind of change that would only take place in Pipil's moribund state. However, completely parallel changes have taken place in other completely viable Nahua dialects, Pipil's sister languages." 
Other authors, such as Hill (1989: 149) and Tsitsipis (1989: 117), see rapidity as a feature that distinguishes change during obsolescence from ordinary processes of change. For example, Hill (1989) provides a careful study of the frequency of use of relative clauses in Mexicano and Cupeño (both Uto-Aztecan languages) and the correlation of these frequencies with the degree of obsolescence of the languages. Dorian (1981: 151) observes that although the types of linguistic change are the same in obsolescence and contact settings, the rate of change may be atypical in the case of language death. Clairis (1991: 9) claims that it is not the presence of a specific feature that is to be considered as a symptom of obsolescence but rather its frequency, compared with the frequency of the feature in healthy languages. Aikhenvald claims that the difference between language change in "healthy" and in endangered or obsolescent languages very often resides in the quantity of change (a massive influx of borrowed forms and patterns as a result of the encroachment of one language on the other), and also in the speed with which this type of language changes. In other words, "an obsolescent language may tend to rapidly become structurally similar to the dominant one" (Aikhenvald, this volume).

In this volume, Alexandra Aikhenvald and Ana Fernández Garay illustrate cases of "gradual death" (Campbell and Muntzel 1989), that is, of languages no longer actively used nor transmitted to the next generation. They observe that speakers of an obsolescent language vary in their proficiency, from "fluent language speakers" to "semi-speakers" and "rememberers" with very limited competence (see also 1998: 441-469).

Sasse (1990: 51) gives some evidence at a linguistic level in favor of a distinction between language contact and language obsolescence, relative to structural changes involving loss of linguistic material. He claims that "Theoretically, contact-induced loss can easily be distinguished from loss due to decay, because the former is motivated by the absence of the respective categories in the contact language, while decay involves loss of categories not motivated in this way." This distinction is not always easy to show, since some types of loss and reduction in obsolescence are associated with types of loss or reduction that can be attributed to contact.

Aikhenvald (this volume) and Fernández Garay (this volume and 1998: 441-469) also state that simplification of syntactic structure, reduction and loss of linguistic material, phonetic fluctuations, and the existence of optional syntax are all consequences of language obsolescence. Aikhenvald notes that "categories absent from the dominant language are particularly endangered." Both illustrate the consequences of contact-induced change in contact settings with different domains. Drawing on synchronic data, Aikhenvald shows that in Tariana, an Arawak language spoken in the multilingual Vaupés area in Brazil, obsolescence is accompanied by a rapidly increasing number of calqued forms and constructions from Tucano, the dominant language of the area. She claims that "before passing into extinction, an obsolescent language may become a 'carbon copy' of the dominant idiom." She explores in particular the domain of personal pronouns, showing that languages that do not have the inclusive versus exclusive opposition in the first person plural may adopt it, as has happened in the case of two Arawak languages, Mawayana and Resígnaro, which, like other languages of this family, do not distinguish an inclusive from an exclusive form. The speakers of Mawayana introduced the Waiwai (Carib family) first person plural exclusive pronoun amna and reinterpreted the original first person plural prefix $w a$ - as inclusive in order to express this opposition. The speakers of Resígnaro have also adopted this opposition from Bora (Bora-Witotoan group), borrowing the Boran first person plural exclusive. In these 
cases, pronouns seem to have been borrowed to fill a perceived gap in the pronominal paradigm.

Borrowing a personal pronoun or a category that deals with a pronominal domain, such as the inclusive/exclusive category, is not very common, although it has been described in certain languages as a result of diffusion in a specific situation of contact (Jacobsen 1980; Thomason and Everett 2005). Thomason and Everett (2005: 307-308) stress the relevance of speakers' decisions: "the crucial point in all these cases is that social factors, not linguistic ones, determine the likelihood of pronominal borrowing. If speakers want to borrow one pronoun or a whole set of pronouns, they can do so; and sometimes speakers do want to do this. The borrowed pronouns may change the structure of the pronominal system significantly, as when a new category of inclusive vs. exclusive 'we' is introduced or lost through borrowing.... extensive lexical and structural borrowing is neither inevitable nor impossible in the most intense contact situations." The important point is that pronominal borrowing seems not to be especially unusual under certain social circumstances, such as intense contact situations. In her contribution, Aikhenvald suggests that these types of borrowing could be the result of a considerable influx of non-native elements (loanwords and replication) and drastic restructuring, which characterize obsolescent languages.

Fernández Garay argues that the existence of a marked-nominative system in Tehuelche, which was probably an ergative language (like the proto-language Protochon), is due to contact with other languages, but that the variations attested and the speed of the process were probably due to the situation of obsolescence. Fernández Garay bases her analysis on language reconstruction and synchronic data. The process, which involves a realignment resulting from the reanalysis and/or extension of an adposition, may be an internal one. Nevertheless, it seems probable that in the case of Tehuelche, the influence of another language in the area helped to transform an ergative language into a marked-nominative one. The coexistence of Tehuelche with Mapudungun, a nominative-accusative language, led the ergative marker or agent marker of the transitive clause to be extended to the intransitive agent, leading to the transformation of this ergative system into a marked-nominative one. Fernández Garay points out that the long and intensive contact with Mapudungun (over at least four centuries) in Tehuelche, an obsolescent language (almost extinct when it was described), may have led to important changes and restructuring in its morphosyntactic structure, showing a loss of a syntactic characteristic. The rise of a marked-nominative system formed part of this restructuring.

\section{Contact-induced change and internally motivated change}

\section{Contact-induced change and principles of grammaticalization}

Contact-induced language change has often been related to the presence or absence of constraints that may explain the borrowing of different kinds of structures (Thomason 2001; Winford 2003). Bernd Heine gives an example of the constraints of principles of grammaticalization on replication in Slavic languages, and Thomas Stolz gives an example of borrowing in Chamorro. They both claim that contact-induced grammaticalization proceeds along a largely predictable sequence of stages and that the stage of grammaticalization in the receiving language never seems to reach the stage of grammaticalization of the source language. They demonstrate that speakers appear to choose a complex strategy going through 
the whole process from numeral to article. The case of the indefinite article illustrates this position.

Heine examines language contact situations in which grammatical meanings or structures are involved. Using three examples (articles, possessive perfects, and the auxiliation of "threaten" verbs) from a range of European languages, he argues that contact-induced grammatical change is constrained by universal principles of grammaticalization. He explains that the constraint on contact-induced grammatical replication suggests that, at least in cases like those discussed in his article, there really is no polysemy copying and the borrowings are not really complete replicas of their models. He suggests that what language contact triggers is a gradual process from a lesser to a greater degree of grammatical structure. In order to illustrate this process, Heine presents an example from Upper Sorbian, a Slavic language which, like other Slavic languages (with the possible exception of Macedonian), is known for the absence of indefinite articles. Language contact seems to have played some role in the rise of the indefinite article in Upper Sorbian. This receiving language seems to have reached the same degree of development as its German model, but Upper Sorbian displays a number of contexts where the replica category is less grammaticalized than the source. Heine develops another example of the rise of the indefinite article in Molisean, probably due to contact with Italian. It is interesting to note that the two Slavic languages (Upper Sorbian and Molisean) exhibiting the most intensive contact with languages that do have indefinite articles are also the ones that have created corresponding articles.

Stolz looks at the use of the indefinite article in Chamorro in order to demonstrate the extent to which the Austronesian morpho-syntax of this language has been affected by the introduction of the indefinite article. He compares his findings with the evidence drawn from other languages whose indefinite articles might turn out to be at least partially the product of language contact with Spanish. The rise of the indefinite article in Chamorro is a consequence of the contact with Spanish - the indefinite article morpheme un is directly borrowed from that language - and its development in the Austronesian language is constrained by universal principles of grammaticalization (see the five-stage scale of Heine 1997, and Heine, this volume). As in other cases discussed by Heine (this volume), the grammaticalization of un has not reached the stage of grammaticalization of Spanish un. However, the indefinite article in modern Chamorro also deviates from the patterns of the Spanish etymological source: the borrowing, integration, and internal development of the article un has generated a category that is neither completely Spanish nor purely Austronesian. This is an example of partial copying (Heine and Kuteva 2005). Stolz demonstrates that there is a preference in language contact situations for an item to replicate first on a low level of grammaticalization in the receiving language, no matter how far the item has advanced on the grammaticalization scale in the source language, and then to continue the process according to known principles of grammaticalization.

\section{"Conspiracy" between contact-induced phenomena and internal phenomena}

Generally, studies on language change only take into account some of the types of mechanism and process reflecting grammatical changes - either internal phenomena or contact-induced phenomena, but not both. Nevertheless, a century ago, Meillet (1982 [1906]: 4, 1982 [1912]: 130-131) argued that the evolution of grammatical structures would imply the presence of processes due to internal change (analogy and grammaticalization) as well as processes related to language contact (borrowing). 
Recently, researchers using a variety of approaches have rethought the distinction between these types of mechanism and have proposed a multi-causal or multi-factorial perspective (Harris and Campbell 1995: 50; Heine and Kuteva 2005; Peyraube 2002; Kriegel 2003; Thomason 2007; Matras 2007; Chamoreau, Estrada, and Lastra in press; Chamoreau and Goury in press). These studies re-examine multi-causality and the distinction of the two types of mechanism.

Heine and Kuteva (2003, 2005) have explored what they called contact-induced grammaticalization, in which language-contact phenomena work in conspiracy with grammaticalization (2008: 218). If the causes, processes, and consequences of language change are multiple, their explanation must be too. This multiplicity reveals both differences and complementarities between the internal mechanisms and the contact-induced ones. The examination of relevant data is a first step, the analysis of their differences and complementarities a second one. The two types of explanation are not contradictory or mutually exclusive; they interact in a complementary manner to produce language change. It is also necessary to show that these two types of change can act and interact in the language processes and at the outcome level.

Four articles here focus on the relationship between contact-induced and internal changes in the causes, processes, and outcomes of change. Patience Epps argues for a multiple causation approach to language evolution, involving a typological understanding of language contact and language change and the exploration of the possible interaction between these two processes. She offers examples from the Vaupés region of northwest Amazonia, a linguistic area characterized by grammatical diffusion among languages from three families (East Tukanoan, Nadahup [Makú], and Arawak). The Vaupés region can also be considered a "grammaticalization area," that is, a region where several languages have undergone (and are currently undergoing) similar processes of grammaticalization. The region is known for its unusual language contact situation, in which resistance to the borrowing of lexical and morphological forms is coupled with a widespread diffusion of grammatical structures and categories that has driven grammaticalization within the recipient languages to generate new forms from existing (native) material to fulfill new functions. In such a context, it is unclear what role, if any, is played by cross-linguistic similarities of form either to limit or promote the transfer of grammatical structures. Epps explores this question through a case study of the etymon $n i$ in Hup (Nadahup/Makú family) and other Vaupés languages. She points out that the similarities among the forms and lexical functions of the $n i$ etymon across the Vaupés languages suggest that contact has played an important role in shaping the current picture, although precisely what should be attributed to contact and what to internal change remains unclear. Nevertheless, she shows that, unusually for this region, $n i$ is represented by a similar constellation of forms and functions across these languages. The case of $n i$ suggests that, in keeping with wider trends of language contact, even in the exceptional context of the Vaupés, elements of shared form may precede and even promote structural borrowing.

Julen Manterola explores Basque definite and indefinite articles and the role of contact in their diachronic evolution. He points out some problems with the ways Basque data have been used in recent contact theories, in particular the Heine and Kuteva contact-induced grammaticalization thesis. He discusses three specific problems. Firstly, the use of only one source does not take distinctive dialectal data into account; empirical knowledge about Basque needs to be brought up to date. Secondly, historical data have been neglected. Thirdly, the function of the ancient plural indefinite article batzu has never been explored. Manterola 
emphasizes the importance of knowledge of the history of the language. He argues for the precautionary principle in language contact studies, especially when diachronic information is not available and no clear data have been found to determine whether a change is contactinduced or internal. He shows that contact effects can conceal the typical diachronic paths of other effects (for example the role of the singular/plural marking overt distinction), and points out an interesting direction for further studies, focusing on the time dimension of language development.

Sibylle Kriegel also argues for the precautionary principle when diachronic data are not available, calling attention to the problem of indeterminacy in dating the copying of elements into Creoles. She analyzes an interesting but neglected case of code copying from languages other than the base language into Creole. For elements that come from the base languages it is very often possible to tell whether they date from the period of creolization or more recently, but the absence of data from the period of constitution of Creoles and the sparse data on their later evolution do not allow for a definite answer. Kriegel sheds new light on the notion of creolization. She demonstrates that two function words of Mauritian and Seychelles Creole, two closely related French-based Creoles, are instances of code copying (Johanson 2002), resulting from the different language contact situations to which these languages were exposed after the abolition of slavery in 1835. The use of depi as an ablative marker in IndoMauritian Creole varieties is interpreted as a covert copy from Bhojpuri, an Indic language which has been in contact with Mauritian Creole since the migration of indentured laborers from Asia. The use of pourdir as a complementizer in some varieties of Seychelles Creole is interpreted as a covert copy from Eastern Bantu languages in contact with Seychelles Creole in the late nineteenth century.

Zarina Estrada Fernández demonstrates that, in the absence of diachronic information, internal reconstruction is an important step to be undertaken in cases where grammatical patterns are involved in language contact situations. In her analysis she takes into consideration not only universal principles of grammaticalization but also the historical changes and typological properties of the language family studied, here the Uto-Aztecan family. She emphasizes the necessity of distinguishing internal and contact-induced change when the processes occur within a family, while recognizing that this is often difficult. She traces the emergence of modal auxiliary verbs in Pima Bajo, one of the Uto-Aztecan languages of northwestern Mexico, as the result of processes involved in verbal complementation, performing a fine-grained exploration of the different possibilities for encoding verbal complements in various languages of this family. She adopts a cautious approach, concluding with two hypothetical explanations for the processes in question but not opting for either one: it is impossible to determine if the development of modal verbs in Pima Bajo should be explained as the result of a structural replication from Spanish or as the result of an internal process with different diachronic pathways.

Anthony P. Grant's article discusses borrowed mechanisms and implicational hierarchies of grammatical borrowing. He too adopts the precautionary principle, in situations where no diachronic data are available or when alternative explanations are possible. Implicational hierarchies show how likely it is that a structural category will be affected by contact-induced change (Matras 2007b). Matras (2007b: 32) explains that two types of generalization may be proposed for the borrowing of grammatical categories. One is "the frequency with which a category may be affected by contact-induced change"; the other type suggests "an implicational relationship between the borrowing of individual categories: the borrowing of 
one category is understood to be a pre-condition for the borrowing of another." Implicational hierarchies show the borrowing tendencies that take place in language contact.

Grant examines major borrowed mechanisms in processes including clause-linking, coordination, complementation, conditionality, and causality in various languages, and discusses the extent to which hierarchies of dependent clause marker borrowing can be established and empirically validated. He notes that several of the languages are documented in considerable chronological depth, while others are less well-described varieties of welldocumented languages, a difficulty for his approach. He explores the processes in question in a global cross-linguistic sample of 22 languages from a wide range of families. In a majority of the languages, the domains of discourse markers, phrasal adverbs, and coordinating, especially subordinating, conjunctions seem to be amenable to language contact. Grant also discusses the implicational hierarchy of conjunction borrowing, since conjunctions are known to be widely borrowed in many of the world's languages. In agreement with studies of much linguists, he demonstrates that general hierarchies of grammatical borrowing have to be seen simply as tendencies. For example, the implicational hierarchy but $>$ or $>$ and is a general tendency confirmed in a large number of languages, but Grant offers counter-examples to the expected pattern: in Livonian and Garifuna, the form meaning 'and' is borrowed while the one meaning 'or' is inherited.

Lastly, Carla Bruno's article focuses on two languages for which diachronic data are available; however, she shows that even in this situation the precautionary principle should be invoked. Against the background of the socio-cultural relations between the Roman and Greek worlds, she proposes a linguistic convergence in Latin and Greek diachrony, that is, the rise of periphrastic constructions consisting of a so-called "possessive" verb form (Lat. habeo and Gr. échō) and a past participle. Pre-existing structural similarities, due to the genetic relationship of the two languages, may have favored mutual shifts of linguistic features as well as their subsequent integration; Bruno compares the extent to which this periphrasis is integrated into each system. Languages change only in accordance with the possibilities given by their system, and Latin and Greek are instances of this rule.

We have put this volume together with a number of goals in mind. First, we have aimed at presenting a number of linguistic phenomena that have not hitherto been described (variations and changes, at a morphosyntactic level, drawn from many diverse languages) and that appear in language contact settings. This diversity of languages and phenomena allows us to test, drawing on contact outcomes already described in the literature, the possibilities and preferences of various languages. Second, we have sought to include cross-linguistic and cross-dialectal perspectives, whatever the specificities of the languages and settings involved. Third, we have tried to show how contemporary approaches and methodologies take into account different (social and linguistic) factors in order to explain contact-induced language change. Multiple causation - a generally accepted phenomenon in the field - identifies both internally motivated changes and contact-induced processes, but the role played by each process and their precise relationship to each other is not always clear. This has led us to favor a multifaceted methodology and a multi-model approach to explaining contact-induced language change. Finally, the studies presented here argue for caution in proposing explanations of contact-induced language changes, both in historical situations, since limited linguistic or sociohistorical knowledge is available, and in contemporary situations, where to date very few social factors have been taken into account (but see Léglise and Chamoreau, to appear). 


\section{References}

Campbell, L. and Muntzel, M. 1989. The structural consequences of language death. In Investigating Obsolescence: Studies in Language Contraction and Death, N. Dorian (ed.), 181-196. Cambridge: Cambridge University Press.

Chamoreau, C., Estrada Fernández, Z., and Lastra, Y. (eds). 2010. A New Look at Language Contact in Amerindian Languages. Munich: Lincom Europa.

Chamoreau, C. and Goury, L. (eds). In press. Contact de langues et changement linguistique. Paris: CNRS Editions.

Clairis, C. 1991. Le processus de disparition des langues. La Linguistique 27.2: 3-14.

Dorian, N. 1981. Language Death: The Life Cycle of a Scottish Gaelic Dialect. Philadelphia: University of Pennsylvania Press.

Faarlund, J. T. 1990. Syntactic Change. Toward a Theory of Historical Syntax. Berlin: Mouton de Gruyter.

Fernández Garay, A. 1998. El Tehuelche. Una lengua en vías de extinción. Valdivia: Universidad Austral de Chile.

Hagège, C. 1993. The Language Builder. Amsterdam: John Benjamins.

Harris, A. and Campbell, L. 1995. Historical Syntax in Cross-Linguistic Perspective. Cambridge: Cambridge University Press.

Heine, B. 1997. Cognitive Foundations of Grammar. Oxford: Oxford University Press.

Heine, B. 2006. Contact-induced word order change without word order change. In Working papers in Multilingualism. Arbeiten zur Mehrsprächigkeit. 76. Hamburg: University of Hamburg.

Heine, B. and Kuteva, T. 2003. On contact-induced grammaticalization. Studies in Language, 27.3: 529-572.

Heine, B. and Kuteva, T. 2005. Language Contact and Grammatical Change. Cambridge: Cambridge University Press.

Heine, B. and Kuteva, T. 2008. The explanatory value of grammaticalization. In Linguistic Universals and Language Change, J. Good (ed.), 215-230. Oxford: Oxford University Press.

Hill, J. 1989. The social functions of relativization in obsolescent and non-obsolescent languages. In Investigating Obsolescence: Studies in Language Contraction and Death, N. Dorian (ed.), 149-164. Cambridge: Cambridge University Press.

Jacobsen, W. H. 1980. Inclusive/exclusive: A Diffused Pronominal Category in Native Western North America. In Papers from the Parasession on Pronouns and Anaphora, J. Kreiman and A. E. Ojeda (eds), 204-230. Chicago: University of Chicago Press.

Johanson, L. 2002. Contact-induced change in a code-copying framework. In Language Change. The Interplay of Internal, External and Extra-Linguistic Factors, M. C. Jones and E. Esch (eds), 285-313. Berlin: Mouton de Gruyter.

Kriegel, S. (ed.). 2003. Grammaticalisation et réanalyse. Approches de la variation créole et francaise. Paris: CNRS Editions.

Lass, R. 1980. On Explaining Language Change. Cambridge: Cambridge University Press. 
Leglise, I and Chamoreau, C. In press. The Interplay of Variation and Change in Contact Settings - Morphosyntactic Studies. Amsterdam: John Benjamins.

Matras, Y. 2007. Socio-cultural and typological factors in contact-induced change. Plenary talk presented at the 'Language Contact and Morphosyntactic variation and change' workshop, Paris, 20-24 September.

Matras, Y. 2007b. The borrowability of structural categories. In Grammatical Borrowing in Cross-Linguistic Perspective, Y. Matras and J. Sakel (eds), 31-73. Berlin: Mouton de Gruyter.

Meillet, A. 1982 [1906]. Comment les mots changent de sens. In Linguistique historique et linguistique générale, 230-271. Paris/Geneva: Champion-Slatkine.

Meillet, A. 1982 [1912]. L'évolution des formes grammaticales. In Linguistique historique et linguistique générale, 131-148. Paris/Geneva: Champion-Slatkine.

Peyraube, A. 2002. L'évolution des structures grammaticales. Langages 146: 46-58.

Romaine, S. 1989. Bilingualism. Oxford: Basil Blackwell.

Sasse, H.-J. 1990. Theory of Language Death and Language Decay and Contact-induced Change: Similarities and Differences. Arbeitspapier No. 12. Cologne: Institut für Sprachwissenschaft, University of Cologne.

Thomason, S. G. 2000. On the unpredictability of contact effects. Estudios de Sociolingüística 1.1: 173-182.

Thomason, S. G. 2001. Language Contact: An Introduction. Edinburgh: Edinburgh University Press.

Thomason, S. G. 2007. On internally- and externally- motivated morphosyntactic change in contact situations (and how to tell which is which). Plenary talk presented at the 'Language Contact and Morphosyntactic variation and change' workshop, Paris, 20-24 September.

Thomason, S. G. and Everett, D. 2005. Pronoun borrowing. Berkeley Linguistics Society 27: 301-315.

Thomason, S G. and Kaufman, T. 1988. Language Contact, Creolization, and Genetic Linguistics. Berkeley: University of California Press.

Tsitsipis, L. 1989. Skewed performance and full performance in language obsolescence: the case of an Albanian variety. In Investigating Obsolescence: Studies in Language Contraction and Death, N. Dorian (ed.), 117-137. Cambridge: Cambridge University Press.

Winford, D. 2003. An Introduction to Contact Linguistics. Oxford: Blackwell. 